UDK 630*423.3(497.11-11 Crni vrh)

Original scientific paper

\title{
THE CROWN CONDITION OF BEECH TREES AFTER THE DISASTROUS ICE STRORM ON MT. CRNI VRH
}

\author{
Miroslava MARKOVIĆ ${ }^{1}$, Snezana RAJKOVIC ${ }^{l}$, Nenad MARKOVIĆ ${ }^{2}$
}

\begin{abstract}
The Level II Sample Plot where the research presented in the paper was conducted is located on Mt. Crni Vrh, in the Dubašnica management unit - compartment 11 - in the area managed by the Boljevac Forest Estate. Thirty marked beech trees (Fagus moesiaca (Domin, Mally) Czeczott.) had the defoliation assessed and the damage determined by class and agent in the growing period of a three-year-long research period. The investigations presented in this paper were performed following the catastrophic ice storm that devastated this area in the winter of 2014. The aim was to monitor the response of trees to a major natural disaster. The results showed that the investigated beech trees had been recovering relatively quickly although they had remained highly vulnerable to the attack of harmful pests and diseases, primarily to the extremely dangerous "beech bark disease", which occurred in the study stand two years after the damaging ice storm. Since beech is a very sensitive species, its condition after a major disaster needs to be monitored regularly at the affected localities in order to prepare and implement a program of adequate measures of protection and thus prevent the disease from growing to epiphytotic proportions or causing a chain of damaging events which could easily spread to the unaffected surrounding areas.
\end{abstract}

Keywords: Sample plot, Beech, Ice Storm, Crown Condition

\footnotetext{
${ }^{1}$ Dr Miroslava Marković, naučni saradnik, Institut za šumarstvo, Beograd

${ }^{1}$ Dr Snezana Rajkovic, naucni savetnik, Institut za sumarstvo, Beograd

2 Autor za kontakt: Nenad Marković, B.Sc., SE`Srbijašume’, Bulevar Mihaila Pupina 113, 11000 Belgrade, tel. +381648155041, Email: marnen67@gmail.com

Acknowledgment: The study was carried out within the Project TR 31070 "The development of technological procedures in forestry with a view to an optimum forest realization", financed by the Ministry of Education, Science and Technological Development of the Republic of Serbia (2010-2020).
} 


\section{СТАЊЕ КРУНА БУКОВИХ СТАБАЛА ПОСЛЕ КАТАСТРОФАЛНОГ ЛЕДОЛОМА НА ЦРНОМ ВРХУ}

Извод: Биоиндикацијска тачка Нивоа II на којој су вршена истраживања приказана у раду, налази се на Црном Врху, у газдинској јединици Дубашница, одељењу 11, на подручју којим газдује ШГ Бољеваи, ШУ Бор. На 30 обележених стабала букве (Fagus moеsiaca (Domin, Mally) Czеczott.) је у вегетаџионом периоду током приказаног периода посматрања у трајању од 3 године, вриена очена дефолијачије и детерминисана очтећења по типовима и врстама узрочника. Испитивања приказана у раду су обављена након ледолома катастрофалних размера који је задесио ово подручје у зиму 2014. године, да би се видела реакција стабала после великих природних непогода. Резултати испитивања су показали да се испитивана стабла букве релативно брзо опорављају, али су врло подложна нападу опасних болести и штеточина, што се првенствено односи на изузетно опасну „болест коре букве“, која се јавила у испитиваној састојини две године након итете од ледолома. Обзиром да је буква и као врста природно врло осетљива, након дејства велике непогоде неопходно је редовно праћење стања на угроженим локалитетима, ради припреме и спровођења програма мера адекватне заштите, да не би дошло до штета епифитотичних размера и евентуалног уланчавања штета, које би се лако могле проширити и на околна, незаражена подручја.

Кључне речи: биоиндикацијска тачка, буква, ледоломи, стање круна

\section{INTRODUCTION}

The impact of pollution and modified climate factors on the vitality of forests has been evident both in Serbia and its wider region and all over Europe. There has been a growing need for research on this topic both in our country and worldwide. In order to determine forest ecosystem processes, it is necessary to conduct detailed research into the environmental factors that lead to the occurrence of harmful insects and diseases and obtain a deeper insight into the state of forests. The results obtained from this research can be used to draw conclusions regarding the necessary measures of improvement which are established through the forest condition monitoring. The ICP Forests is a programme of monitoring the impact of anthropogenic (primarily air pollution) and biotic harmful factors on the state and development of forest ecosystems in Europe. With the cooperation of the Forest Directorate and the Institute of Forestry in Belgrade as the National Focal Center (NFC) of the Republic of Serbia for forest condition monitoring this system of forest monitoring has been integrated into the state forestry environment, so that several institutions with their associates has been participating in the program (Gagic-Serdar et al., 2018).

The ice storm that hit the whole of eastern Serbia in late November and early December 2014 caused significant damage to the areas managed by SE Srbijašume, i.e. forest estates of Niš, Boljevac, Kruševac, Despotovac and Kučevo. More than $400,000 \mathrm{~m}^{3}$ of wood was damaged in the state forests alone and the storm affected an area of over 19,000 ha. All the affected surface areas were mapped in GIS technology (Marković, \& Marković, 2018). 
The areas that suffered the consequences of the ice storm in 2014 (about 17,000 ha) are largely located in the altitudinal belt of $600-900 \mathrm{~m}$ a.s.l., i.e., in the belt of low mountains. Most of the affected areas have a northern (about 4,000 ha) or a northeastern aspect (about 3,500 ha), and the remaining surface areas are evenly distributed over the other aspect classes. The impact of the terrain slope on the occurrence of ice breaks was not significant (Marković \& Marković, 2018). This natural disaster had severe and far-reaching consequences on the coniferous and broadleaved forest ecosystems and the environment in general. These consequences included the changes in the soil water regime, erosion, oxygen reduction, reduced amounts of carbon accumulated in biomass. However, the degradation processes that are yet to occur will cause the regressive degradation of forest communities and the depletion of soil that will be inhabited by those tree species that represent the earliest stages in the ontogeny of forest stands.

Considering the size of the forest area affected by the ice storm, as well as its enormous impact on the environment, this natural disaster can be considered catastrophic.

The stands affected by the ice storm are largely beech stands because Serbia is a country in which beech (Fagus moessaca (Domin, Mally) Czeczott.), either in pure or mixed stands, accounts for about $60 \%$ of wood volume. The beech has a wider horizontal and vertical distribution than any other species in our country, which highlights its great importance for the forest economy in Serbia. Beech stands are found both at low altitudes (at $70 \mathrm{~m}$ around Negotin) and at up to $1,500 \mathrm{~m}$ in large mountain massifs. Furthermore, beech has retained its natural structure, as well as its natural range of distribution and natural regeneration capacity. There are not any artificially-established beech stands in Serbia because the only way to restore beech forests is through natural regeneration. The biological properties, ecological requirements, natural range of distribution, multiplepurpose benefits and natural structure of stands make beech the main tree species of Serbian forestry.

Bearing in mind the fact that beech trees are very susceptible to the attack of harmful insects or pathogenic and epyxilic fungi, there is a pressing need to investigate the factors that affect its health state in order to develop a program of measures for its systematic protection.

The paper gives an overview of the health state of 30 beech trees monitored at the Crni Vrh site (where the level II sample plot is located). The health state was defined through the defoliation and occurrence of diseases and pests in the period from 2015 to 2017, following the natural disaster and during the implementation of sanitary cutting, cleaning and removing of broken branches. 


\section{MATERIAL AND METHODS}

\subsection{Material}

The sample plot where the presented research was conducted is located on Mt. Crni Vrh, in the Dubašnica management unit, compartment 11, managed by the FE Boljevac, FA Bor. The plot is at + 44007'55" (Latitude) and + 21058'38" (Longitude) in an even-aged beech (Fagus moesiaca) high stand. The stand is 60 years old. The basic characteristics of the forest ecosystem are as follows: the site is at $1086-1155 \mathrm{~m}$ above sea level; the aspect is southern and southwestern; the slope is uniform, steep, with the slope degree of $11-15^{0}$; the bedrock is composed of decomposed phyllite and the soil is classified as a fresh, medium-deep, dystric brown soil; dead organic layer is moderately represented with a favourable process of humification; the ground vegetation is sparse and the shrub layer is absent.

Every year, the degree of defoliation is assessed and the damage (entomological, phytopathological, and mechanical) to the marked trees is determined by types and species of agents during the growing period. The assessment also includes the location of the damage (leaves, branches, bark, trunk portion, butt end, root, etc.).

\subsection{Methods of crown condition assessment}

The crown defoliation is evaluated based on the branch die-off and expressed in percentages from 0 to $100(0 \%$ of defoliation defines the trees without dying branches, and $100 \%$ the trees with no living branches).

In order to make the results more comprehensive, the following table presents the damage in codes, classified by agent type, agent species, damaged tree part, and damage intensity.

For the assessment to present the real state of the tree health, it was carried out during the growing period (since autumnal leaf discolouration can affect the assessment of defoliation and discolouration and lead to wrong assumptions regarding the tree crown condition). The assessments were carried out on 5 August 2015, 27 July 2016 and 14 September 2017. The basic data regarding the sample plot on Mt. Crni Vrh are given in the PLT tables, Tables 1, 2 and 3 and refer to each year of the research respectively.

Table 1. XX2012. (PLT) Data regarding the plot selected for the crown condition assessment, Level II, Crni Vrh

\begin{tabular}{|c|c|c|c|c|c|c|c|c|}
\hline $\begin{array}{c}\text { Sequence } \\
\text { number }\end{array}$ & $\begin{array}{c}\text { Country } \\
\text { Code }\end{array}$ & $\begin{array}{c}\text { Observatio } \\
\text { n plot }\end{array}$ & $\begin{array}{c}\text { Date of } \\
\text { assessm } \\
\text { ent }\end{array}$ & Latitude & Longitude & Altitude & $\begin{array}{c}\text { Team } \\
\text { identification }\end{array}$ & $\begin{array}{c}\text { Other } \\
\text { observations }\end{array}$ \\
\hline 1 & 67 & 4 & 050815 & $+44007^{\prime} 55^{\prime \prime}$ & $+21058^{\prime} 38^{\prime \prime}$ & 19 & & \\
\hline
\end{tabular}


Table 2. XX2012. (PLT) Data regarding the plot selected for the crown condition assessment, Level II, Crni Vrh

\begin{tabular}{|c|c|c|c|c|c|c|c|c|}
\hline $\begin{array}{c}\text { Sequence } \\
\text { number }\end{array}$ & $\begin{array}{c}\text { Country } \\
\text { Code }\end{array}$ & $\begin{array}{c}\text { Observatio } \\
\text { n plot }\end{array}$ & $\begin{array}{c}\text { Date of } \\
\text { assessm } \\
\text { ent }\end{array}$ & Latitude & Longitude & Altitude & $\begin{array}{c}\text { Team } \\
\text { identification }\end{array}$ & $\begin{array}{c}\text { Other } \\
\text { observations }\end{array}$ \\
\hline 1 & 67 & 4 & $\begin{array}{c}200416 \\
270716\end{array}$ & $+44^{0} 07^{\prime} 55^{\prime \prime}$ & $+21^{0} 58^{8} 38^{\prime \prime}$ & 19 & & \\
\hline
\end{tabular}

Table 3. XX2012. (PLT) Data regarding the plot selected for the crown condition assessment, Level II, Crni Vrh

\begin{tabular}{|c|c|c|c|c|c|c|c|c|}
\hline $\begin{array}{c}\text { Sequence } \\
\text { number }\end{array}$ & $\begin{array}{c}\text { Country } \\
\text { Code }\end{array}$ & $\begin{array}{c}\text { Observatio } \\
\text { n plot }\end{array}$ & $\begin{array}{c}\text { Date of } \\
\text { assessm } \\
\text { ent }\end{array}$ & Latitude & Longitude & Altitude & $\begin{array}{c}\text { Team } \\
\text { identification }\end{array}$ & $\begin{array}{c}\text { Other } \\
\text { observations }\end{array}$ \\
\hline 1 & 67 & 4 & 140917 & $+44^{0} 07^{\prime} 55^{\prime \prime}$ & $+21^{0} 58^{\prime} 38^{\prime \prime}$ & 19 & & \\
\hline
\end{tabular}

\section{RESULTS AND DISCUSSION}

The improved methodological approach of the Level II crown condition assessment can be described as systematic monitoring of a set of characteristics of dominant tree crowns on the sample plots. The results of intensive monitoring assessments (Nevenić et al., 2011) conducted for each individual tree whose crown is monitored every year, will after a certain number of replications give answers to different hypothetical assumptions, such as the causes of the serious deterioration of forest vitality (by identifying the causes and applying the expert knowledge in dealing with them).

Intensive monitoring will eliminate the error factor from the evaluation of the current state and the application of standard laboratory methods will provide clear interpretation and detailed explanation of defoliation percentage values.

Intensive crown condition monitoring is focused on the assessments of defoliation and identification of damage. It can further include other parameters, such as tree status, crown shading, crown visibility, fruiting of the visible part of the crown, the presence of secondary shoots, etc.

\subsection{Results regarding the health condition of individual beech trees, by year}

When inspecting the marked trees, the health state of each individual tree was determined by assessing the branch die-off or defoliation from 0 to $100 \%$ and the damage caused by the effects of harmful abiotic and biotic factors on the leaves, branches, and trunks. The damage is presented in the codes defined in the legend below Table 4 . 


\subsubsection{The description of the 2015 results}

The tree health inspection was conducted on 5August 2015. The inspection included 30 beech trees marked for this purpose on subplot 2. On that occasion, their defoliation was assessed, the intensity of the damage caused by abiotic and biotic agents determined and other observations were made. The basic data regarding the intensive monitoring plot on Mt. Crni Vrh are given in the PLT table (Table 1). Table 4 gives the crown condition parameters and the damage parameters for the sample plot in 2015 and during the entire research period.

Although the inspection revealed that the majority of broken trees or their parts had been removed from the stand and it had been largely cleared, all the trees still showed the signs of the damage caused by ice, mostly in the top parts of the crowns, while the other tree crown parts had increasing defoliation values (5 trees had a defoliation of 80 to $90 \%, 9$ trees $20-35 \%, 8$ trees $10-15 \%$, and only 9 trees had a defoliation of 0 to 5\%.) There was one fallen tree and one stag tree. There were mining insects on the leaves (the foliar damage caused by insects was observed in almost all trees). The presence of the harmful insect known as Cryptoccocus fagisuga was observed on the bark of 4 trees.

\subsubsection{The description of the 2016 results}

The tree health inspection was conducted twice, in the spring and in the summer of 2016 (20 April and 27 July, 2016). The inspection included 30 beech trees marked for this purpose on subplot 2.Their defoliation was assessed, the intensity of the damage caused by abiotic and biotic agents was determined and other observations were made. The basic data regarding the intensive monitoring plot on Mt. Crni Vrh are given in the PLT table (Table 2). Table 4 gives the crown condition parameters and the damage parameters for the sample plot in 2016 and during the entire study period.

It was observed that there had been no newly fallen or dead timber. Of other observations, it is important to note that the beech trees had drastically lower defoliation degree values in the summer inspection than in the inspection conducted in the spring of 2016, and several trees had their leaves again, mainly in whiskers. It proved that the trees had been recovering quickly and noticeably from the damage caused by the ice storm. One tree had a bark burn and a large number of trees still had broken branches and decay that generally develops through wounds.

Given the overall extent of the damage caused by the ice storm, its effects inevitably included the occurrence of the pathogenic fungus Nectria coccinea on the broken parts of the investigated trees. Together with Cryptococcus fagisuga it is notorious for causing a very serious disease known as the "beech bark disease".

\subsubsection{The description of the 2017 results}

The tree health inspection was conducted on 14 September 2017. The assessment included 30 beech trees selected for the annual crown condition monitoring on subplot 2. On that occasion, their defoliation was assessed, the 
intensity of the damage caused by abiotic and biotic agents determined and other observations made. The basic data regarding the intensive monitoring plot on Mt. Crni Vrh are given in the PLT table (Table 3). Table 4 gives the crown condition parameters and the damage parameters for the sample plot in 2017 and the previous two years.

It was noted that two more trees had died, but there weren't any newly fallen trees. The bark burn caused by the effects of an abiotic factor (prolonged exposure to sunlight) was present only in one tree as in the previous year (tree 74), and a larger number of trees still had broken branches and decay that developed through wound sites. Trees 68,72 and 91 were still standing, but they were completely decayed, and tree 95 had already decayed and fallen in the previous years. The effects of the ice storm that hit this stand could also be seen on trees 78 and 87 which had broken tips as a consequence of this disaster. Furthermore, several trees had the larger branches of their crowns broken during the ice storm (No. 58, 67, 73, 79 , and 100). Tree 89 had a very strong defoliation of $85 \%$, as well as the centre rot, and substantial mechanical damage which will probably lead to its death in the following year. Compared to the previous year, it was obvious that the stand can had been restoring gradually from this harmful abiotic agent. This was also proven by the defoliation values which had decreased noticeably and now ranged from 5 to $30 \%$.

The harmful biotic agents present in the stand primarily referred to the presence of the Cryptococcus fagisuga Lind. colonies which transmit the spores of Nectria coccinea (Pers. ex Fr.) Fries. This fungal pathogen causes the bark canker and eventually kills trees. It is one of the most serious fungi that occur on beech trees, and together with the insect $C$. phagisuga causes the so-called "beech bark disease". After a tree has been infected by $N$. coccinea, the necrotic zone of the bark is quickly colonized by wood-decaying fungi and xylophagous insects. The degradation of the trees attacked by these secondary organisms is relatively fast.

Other biotic factors that affected the beech trees included the branch decay (Trees 73 and 100) and the center rot (Tree 89). Several trees had the Diatrype stigma (Hoffm.) fungus on their trunks, but it didn`t produce any significant effects on the trees.

\subsection{The study results regarding the beech tree health state for the entire research period, collectively}

Table 4. Comparative review of the beech tree defoliation and damage after the ice storm (in the period from 2015 to 2017)

\begin{tabular}{|c|c|c|c|c|c|c|c|c|}
\hline \multirow[b]{2}{*}{$\begin{array}{c}\text { Tree } \\
\text { number }\end{array}$} & \multicolumn{4}{|c|}{2015} & \multicolumn{4}{|c|}{2016} \\
\hline & Defoliation & $\begin{array}{c}\text { Scientific } \\
\text { name of } \\
\text { cause }\end{array}$ & $\begin{array}{l}\text { Location } \\
\text { in crown }\end{array}$ & Extent & Defoliation & $\begin{array}{c}\text { Scientific } \\
\text { name of } \\
\text { cause }\end{array}$ & $\begin{array}{l}\text { Location } \\
\text { in crown }\end{array}$ & Extent \\
\hline 57 & 10 & & & & 0 & 430 & 3 & 3 \\
\hline 58 & 5 & 430 & 3 & 3 & 5 & 390 & 3 & 1 \\
\hline 62 & 15 & 390 & 3 & 1 & 15 & & & \\
\hline 64 & 20 & & & & 15 & & & \\
\hline 65 & 5 & & & & 5 & 390 & 3 & 1 \\
\hline 66 & 20 & 390 & 3 & 1 & 20 & 290 & 3 & 1 \\
\hline 67 & 15 & 290 & 3 & 1 & 15 & 290 & 3 & 1 \\
\hline 68 & 100 & 290 & 3 & 1 & 100 & \multicolumn{3}{|c|}{ Decayed } \\
\hline 69 & 0 & & & & 0 & 290 & 3 & 1 \\
\hline
\end{tabular}




\begin{tabular}{|c|c|c|c|c|c|c|c|c|}
\hline \multirow[b]{2}{*}{$\begin{array}{c}\text { Tree } \\
\text { number }\end{array}$} & \multicolumn{4}{|c|}{2015} & \multicolumn{4}{|c|}{2016} \\
\hline & Defoliation & $\begin{array}{c}\text { Scientific } \\
\text { name of } \\
\text { cause }\end{array}$ & $\begin{array}{l}\text { Location } \\
\text { in crown }\end{array}$ & Extent & Defoliation & $\begin{array}{c}\text { Scientific } \\
\text { name of } \\
\text { cause }\end{array}$ & $\begin{array}{l}\text { Location } \\
\text { in crown }\end{array}$ & Extent \\
\hline 71 & 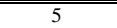 & 290 & 3 & 3 & 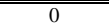 & 430 & 3 & 3 \\
\hline 72 & 90 & 430 & 3 & 1 & 90 & & & \\
\hline 73 & 10 & & & & 0 & & & \\
\hline 74 & 0 & & & & 0 & 290 & 3 & 1 \\
\hline 75 & 5 & 290 & 3 & 1 & 0 & 290 & 3 & 1 \\
\hline 76 & 25 & 290 & 3 & 1 & 0 & 290 & 3 & 1 \\
\hline 77 & 15 & 290 & 3 & 1 & 40 & & & \\
\hline 78 & 80 & & & & 70 & 290 & 3 & 2 \\
\hline 79 & 15 & 290 & 3 & 1 & 5 & 290 & 3 & 1 \\
\hline 87 & 80 & 290 & 3 & 1 & 50 & 390 & 3 & 1 \\
\hline 88 & 5 & 390 & 3 & 1 & 5 & 290 & 3 & 1 \\
\hline 89 & 80 & 290 & 3 & 1 & 60 & & & \\
\hline 90 & 30 & & & & 5 & 290 & 3 & 1 \\
\hline 91 & 90 & 290 & 3 & 1 & 70 & & & \\
\hline 92 & 30 & & & & 10 & 290 & 3 & 1 \\
\hline 94 & 15 & 290 & 3 & 1 & 15 & 390 & 3 & 1 \\
\hline 95 & 40 & 390 & 3 & 7 & \multicolumn{4}{|c|}{ fallen } \\
\hline 96 & 25 & 430 & 3 & 1 & 10 & 390 & 3 & 1 \\
\hline 97 & 10 & 390 & 3 & 1 & 30 & 290 & 3 & 1 \\
\hline 98 & 0 & 290 & 3 & 1 & 10 & & & \\
\hline 100 & 5 & & & & 10 & 290 & 3 & 1 \\
\hline
\end{tabular}

\begin{tabular}{|c|c|c|c|c|}
\hline \multirow{2}{*}{ Tree number } & \multicolumn{4}{|c|}{2017} \\
\hline & Defoliation & $\begin{array}{c}\text { Scientific } \\
\text { name of } \\
\text { cause }\end{array}$ & $\begin{array}{l}\text { Location } \\
\text { in crown }\end{array}$ & Extent \\
\hline 57 & $\begin{array}{l}5 \\
\end{array}$ & 432 & 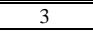 & 3 \\
\hline 58 & 15 & & & \\
\hline 62 & 15 & & & \\
\hline 64 & 15 & & & \\
\hline 65 & 5 & & & \\
\hline 66 & 25 & & & \\
\hline 67 & 20 & & & \\
\hline 68 & 100 & \multicolumn{3}{|c|}{ Decayed } \\
\hline 69 & 5 & & & \\
\hline 71 & 0 & & & \\
\hline 72 & 100 & \multicolumn{3}{|c|}{ Decayed } \\
\hline 73 & 5 & 390 & 3 & 1 \\
\hline 74 & 5 & & & \\
\hline 75 & 5 & & & \\
\hline 76 & 20 & & & \\
\hline 77 & 20 & & & \\
\hline 78 & 30 & & & \\
\hline 79 & 10 & & & \\
\hline 87 & 20 & 432 & 3 & 1 \\
\hline 88 & 5 & & & \\
\hline 89 & 85 & & & \\
\hline 90 & 5 & & & \\
\hline 91 & 100 & \multicolumn{3}{|c|}{ Decayed } \\
\hline 92 & 25 & & & \\
\hline 94 & 10 & & & \\
\hline 95 & \multicolumn{4}{|c|}{ fallen } \\
\hline 96 & 20 & & & \\
\hline 97 & 20 & & & \\
\hline 98 & 10 & & & \\
\hline 100 & 10 & & & \\
\hline
\end{tabular}

Legend (the codes used in the table)

\section{Damage cause:}

290 - biotic, insects

390 - biotic, fungi

430 - abiotic, snow and ice

432 - abiotic, frost cracks
Location in crown Damage intensity:

3 - patches

1-damage of 1-10\%

2 - damage of $11-20 \%$

3 - damage of $21-40 \%$

7 - damage of $100 \%$ 
As shown in Table 4, defoliation was reduced during the study period, particularly in the trees with lower defoliation percentages and in the last year of the research, that is, 4 years after the ice storm. The trees with very high defoliation percentages eventually decayed, broke or fell. Some trees that had high percentages of defoliation in the upper crown reduced the defoliation drastically over time, as these dead branches broke and fell off. On the basis of these results, it could be said that the general condition of the study stand had been improving.

Regarding the damage registered on the investigated beech trees, we can note that the damage was drastically reduced in the last year of the research, which means that the trees built up their resistance after they had been affected by the ice storm.

\section{CONCLUSIONS}

As the most common tree species in Serbia and due to its excellent technical characteristics, the beech is ranked as a species of great significance in the forest economy. However, a wider use of beech wood is limited by its poor durability. The wood is rated as non-resistant and makes suitable grounds for the development of many parasitic and saprophytic organisms, above all parasitic fungi and harmful insects. For instance, some literature sources state that the high (seeds) and coppice beech forests in Serbia host almost 150 species of fungi on their trees, some of which can be found on the cupules, fruit and seedlings, some on the leaves and branch and stem bark, and some cause wood decay and staining.

It is important to emphasize that the beech forest decline has been caused by the interaction of the adverse effects of climate change and the management and biotic factors. One of these adverse factors is naturally the human activity. Unreasonable exploitation of beech forests in Serbia has almost halved the area under forest. The felling of beech forests in the past (especially immediately after the Second World War) was not aimed at forest regeneration, but almost exclusively at wood exploitation. Consequently, beech trees have become nonresistant to the harmful effects of numerous abiotic and biotic factors. Among them, the most serious biotic factors are parasitic fungi and harmful insects. The spread of the dangerous "beech bark disease" caused by the Cryptococcus fagisuga insect and the Nectria coccinea fungus makes the protection of beech forests even more difficult.

This study shows that despite the fact that the beech is a very sensitive species, if proper care and management measures are carried out, beech trees can recover relatively quickly even from the substantial damage caused by natural disasters such as catastrophic ice storms.

However, one must bear in mind the fact that the physiologically weakened trees are much more susceptible to the attack of dangerous diseases and pests, which in this case refers to the extremely dangerous "beech bark disease" that occurred in the study stand two years after the ice storm. It is therefore necessary to conduct regular monitoring of these localities in the coming period in order to prepare and implement programs of measures of adequate protection for the 
prevention of the damage of epiphytic proportions, which could easily spread to the surrounding non-infected areas.

\section{REFERENCES}

Bilibajkić, S., Nevenić, R., Marković, M., Češljar, G., Stefanović, T., Poduška, Z., Đorđević, I., Gagić Serdar, R. (2014): Intensive Monitoring on the Level II Sample Plots Kopaonik, Crni Vrh and Mokra Gora in 2014. Sustainable Forestry Journal, Vol. 69-70, Institute of Forestry, Belgrade. ISSN 1821-1046. UDK 630, pp. 95-109.

http://www.forest.org.rs/files/Sustainable\%20Forestry\%20\%20Collection\%20of\%20works\%2069-70,\%20year\%202014.pdf

Gagić Serdar R Stefanović T Đorđević I Češljar G Marković M 2018 E Forest Vitality (ICP Level I Sample Plots) with a special Emphasis on Biotic Agents in the Republic of Serbia in 2018 Sustainable Forestry Vol 77-78 ISSN 1821-1046 UDK 630 COBISS.SR-ID 157148172 (Publisher Institute of Forestry Belgrade Serbia) pp 55-66 http://www.forest.org.rs

Nevenić et al 2008 Monitoring of the state of forests in the Republic of Serbia according to the ICP Forest Programme (International Cooperative Programme for $65^{\text {th }}$ Monitoring of the State of Forests of Europe) and the CLTRAP Convention (Convention on Transboundary Air Pollution Transmission) Annual report for 2008 National Focal Center of Serbia (NFC) ICP Forests - Level I (Institute of Forestry Belgrade Serbia) p 15

Nevenić R Tabaković-Tošić M Rajković S Rakonjac Lj Miletić Z Marković M Bilibajkić S Stefanović T Jović Đ Radulović Z Stajić S Čokeša V Mladenović K Poduška Z Đorđević I Češljar G 2011 Praćenje i procena uticaja zagađenja vazduha i njegovih efekata u šumskim ekosistemima na teritoriji Srbije - Monitoring stanja šuma Nivo I i Nivo II Monitoring and assessment of the impact of air pollution and its effects on forest ecosystems in the territory of Serbia - Forest Condition Monitoring, Level I and Level II Chapter I (Institute of Forestry Belgrade) ISBN 98786-80439-28-0

Nevenić R., Tabaković-Tošić M., Rajković S., Rakonjac Lj., Miletić Z., Marković M., Bilibajkić S., Stefanović T., Stajić S., Čokeša V., Radulović Z., Poduška Z., Gagić-Serdar R., Đorđević I., Češljar G., (2012): Procena i praćenje efekata-uticaja vazdušnih zagađenja na šumske ekosisteme u Republici Srbiji. Nivo I i Nivo II. Monitoring and assessment of the impact of air pollution and its effects on forest ecosystems in the Republic of Serbia, Level I and Level II, (Chapters 4, 5, 6, 7, 9, $10,13,16)$ ISSN $1425 / 8576$

Nevenić R., Tabaković-Tošić M., Rajković S., Rakonjac Lj., Miletić Z., Marković M., Bilibajkić S., Stefanović T., Stajić S., Čokeša V., Radulović Z., Poduška Z., Gagić-Serdar R., Đorđević I., Češljar G., (2013): Procena i praćenje efekata-uticaja vazdušnih zagađenja na šumske ekosisteme u Republici Srbiji. Nivo I i Nivo II. Monitoring and assessment of the impact of air pollution and its effects on forest ecosystems in the Republic of Serbia, Level I and Level II, (Chapters 4, 5, 6, 7, 9, $10,13,16)$ ISBN 987-86-80439-35-8

Nevenić, R., Bilibajkić, S., Marković, M., Češljar, G., Stefanović, T., Đorđević, I., Poduška, Z. (2013): Tree Crown Condition at Level II Sample Plots Kopaonik, Crni Vrh and Mokra Gora in 2013. Sustainable Forestry Journal, Vol. 67-68, Institute of Forestry, Belgrade. ISSN 1821-1046. UDK 630, pp.79-94. http://www.forest.org.rs/pdf/Sustainable Forestry, Tom 67-68.pdf 
Nevenić R., Tabaković-Tošić M., Rajković S., Rakonjac Lj., Miletić Z., Marković M., Bilibajkić S., Stefanović T., Stajić S., Čokeša V., Radulović Z., Poduška Z., Gagić-Serdar R., Đorđević I., Češljar G., (2014): Procena i praćenje efekata-uticaja vazdušnih zagađenja na šumske ekosisteme u Republici Srbiji. Nivo I i Nivo II. Monitoring and assessment of the impact of air pollution and its effects on forest ecosystems in the Republic of Serbia, Level I and Level II, (Chapters 4, 5, 6, 7, 9, $10,13,16)$ ISBN 987-86-80439-35-8

Nevenić R., Tabaković-Tošić M., Rajković S., Rakonjac Lj., Miletić Z., Marković M., Bilibajkić S., Stefanović T., Stajić S., Čokeša V., Radulović Z., Poduška Z., Gagić-Serdar R., Đorđević I., Češljar G., (2015): Procena i praćenje efekata-uticaja vazdušnih zagađenja na šumske ekosisteme u Republici Srbiji. Nivo I i Nivo II. Monitoring and assessment of the impact of air pollution and its effects on forest ecosystems in the Republic of Serbia, Level I and Level II, (Chapters 4, 5, 6, 7, 9, $10,13,14)$ ISBN 987-86-80439-35-8

Nevenić R., Tabaković-Tošić M., Rajković S., Rakonjac Lj., Miletić Z., Marković M., Bilibajkić S., Dražić D., Veselinović M., Eremija S., Radulović Z., Stefanović T., Stajić S., Čokeša V., Đorđević I., Poduška Z., Gagić-Serdar R., Češljar G., Čule N., (2016): Procena i praćenje efekatauticaja vazdušnih zagađenja na šumske ekosisteme u Republici Srbiji. Nivo I i Nivo II. Monitoring and assessment of the impact of air pollution and its effects on forest ecosystems in the Republic of Serbia, Level I and Level II, (Chapters 4, 5, 6, 10, 12, 13, 14, 15, 16) ISBN 987-86-80439-35-8

Nevenić R., Tabaković-Tošić M., Rajković S., Rakonjac Lj., Miletić Z., Marković M., Bilibajkić S., Dražić D., Veselinović M., Eremija S., Stefanović T., Stajić S., Mitrović S., Čule N., Radulović Z., Čokeša V., Đorđević I., Gagić-Serdar R., Češljar G., (2017): Procena i praćenje efekata-uticaja vazdušnih zagađenja na šumske ekosisteme u Republici Srbiji. Nivo I i Nivo II. Monitoring and assessment of the impact of air pollution and its effects on forest ecosystems in the Republic of Serbia, Level I and Level II, (Chapters 4, 5, 6, 10, 12, 13, 14, 15, ) ISBN 987-86-80439-35-8

Nevenić R., Tabaković-Tošić M., Rajković S., Rakonjac Lj., Miletić Z., Marković M., Bilibajkić S., Dražić D., Veselinović M., Eremija S., Stefanović T., Stajić S., Mitrović S., Čule N., Radulović Z., Čokeša V., Đorđević I., Gagić-Serdar R., Češljar G., (2018): Procena i praćenje efekata-uticaja vazdušnih zagađenja na šumske ekosisteme u Republici Srbiji. Nivo I i Nivo II. Monitoring and assessment of the impact of air pollution and its effects on forest ecosystems in the Republic of Serbia, Level I and Level II, (Chapters 4, 5, 6, 10, 12, 13, 14, 15, 17) ISBN 987-86-80439-35-8

Marković M., Rajković S., Rajković, R. (2012): “Analysis of the impact of injuries caused by the influence of mechanical and abiotic factors on the occurrence of harmful fungal organisms", Sustainable Forestry, Vol. 65-66, pp. 97-102, ISSN 1821-1046, UDK 630, Publisher: Institute of Forestry, Belgrade, Serbia http://www.forest.org.rs

Marković M., Rajković S., Cokesa, V. (2012): "The Occurrence and Development of Fungi on Trees with Mechanical Injuries under the Influence of the Anthropogenic Factor and Climatic Changes", International Scientific Conference "Forests in the Future-Sustainable Use, Risks and Challenges", 4-6 October 2012, Belgrade, Serbia, Proceedings, pp. 297-303,630(082)(0.034.2) ISBN 987-86-80439-33-4 COBISS.SR-ID 195909644 http://www.forest.org.rs 
Marković, M., Mitić, D., Rajković, S., Rakonjac, LJ., Lučić, A., Marković, M., Rajković, R. (2013): "Analysis of the link between injuries on forest trees and the presence of harmful fungal organisms", Scientific Research and Essays, 18 September, Vol 8(35), pp. 16881700, ISSN 1992-2248, DOI 10.5897/SRE12.412 http://www.academicjournals.org/SRE

Marković M., Rajković S., Nevenić, R. (2014): The Most Frequent Agents Of Damage Of Trees On The Sample Plots In Serbia: Sustainable Forestry, Collection of Papers 69-70, Institute of Forestry, Belgrade, pp. 85-94 http://www.forest.org.rs

Marković M., Rajković S., Rakonjac, Lj. (2017): “Injuries to living Trees at the Sample Plots in Central Serbia", $6^{\text {th }}$ ICP Forests Scientific Conference "Air pollution, climate change and forest ecosystems: Evidence for effects, adaptation, and mitigation", 16-18 May, Bucharest, Romania, Abstracts p. 24

Marković, N., Marković, M. (2018): "Disastrous Ice Breaks in Eastern Serbia - GIS Analysis of their Relationship with Orographic Characteristics", Sustainable Forestry, pp. 67-76, Vol. 77-78, ISSN 1821-1046 UDK 630 COBISS.SR-ID 157148172 Publisher: Institute of Forestry, Belgrade, Serbia http://www.forest.org.rs

Rajković S., Marković M., Milanović, S., Mladenović, K. (2012): "Development of major pathogens and pests influenced by the abiotic and biotic factors", International Scientific Conference "Forests in the Future-Sustainable Use, Risks and Challenges",4-6 October 2012, Belgrade, Serbia, Invited paper, pp. 119-130 ISBN: 978-86-80439-31-0, Organizer : Institute of Forestry Belgrade, Serbia; International Union of Forest Research Organizations; European Forest Institute; International Centre of Forestry and Forest Industries; Faculty of Applied Ecology Futura, Belgrade, Serbia http://www.forest.org.rs

Rajković S., Marković M., Rakonjac, Lj. (2012): "The influence of biotic and abiotic factor on the occurrence and development of pathogens", $13^{\text {th }}$ International Congress of the Society for Ethnopharmacology, Graz, Austria, 2-6 September, Book of Abstracts, p. 217, Organizer: Institute of Pharmaceutical Sciences, Department of Pharmacognosy KarlFranzens-University Graz, Society for Medicinal Plant and Natural Product Research and Eurasia Pacific Uninet http://ise13.uni-graz.at

Rajković S., Marković M., Rakonjac, Lj. (2016): "Monitoring Plot - Crni Vrh - Ozone injury", $5^{\text {th }}$ ICP Forests Scientific Conference "Tracing air pollution and climate change effects on forest ecosystems: trend and risk assessments", 10-12 May - Luxembourg 2016, Abstracts, p. 31, ISBN 978-3-926301-03-1, Organizer: Thünen Institute, Hamburg Bergedorf, Le Gouvernement du Grand-Duché de Luxembourg, Ministre du Development durable et des infrastructures, Administration de la nature et des forests, Luxembourg. www.icp-forests.net

Rajković S, Marković, M. (2018): “Ozone injury - Kopaonik - Level II”. European forests in a changing environment: "Air pollution, climate change and forest management: $7^{\text {th }}$ Forest Scientific Conference“, 22-23 May, Riga, Latvia, Abstracts pp. 38

*****(2005): Monografija "Bukva (Fagus moesiaca /Domin, Mally/ Czeczott.)u Srbiji", Monograph "Beech (Fagus moesiaca /Domin, Mally/ Czeczott) in Serbia", Faculty of Forestry, Belgrade 
*****(2010): Manual on methods and criteria for harmonized sampling, assessment, monitoring and analysis of the effects of air pollution on forests, United Nations Economic Commission For Europe Convention On Long-Range Transboundary Air Pollution, Institute for World Forestry. Programme Coordinating Centre of ICP Forests.

\title{
THE CROWN CONDITION OF BEECH TREES AFTER THE DISASTROUS ICE STRORM ON MT. CRNI VRH
}

\author{
Miroslava MARKOVIĆ, Snezana RAJKOVIC, Nenad MARKOVIĆ
}

\begin{abstract}
Summary
As the most common tree species in Serbia and due to its excellent technical characteristics, the beech is ranked as a species of great significance in the forest economy. However, a wider use of beech wood is limited by its poor durability. The wood is rated as non-resistant and makes suitable grounds for the development of many parasitic and saprophytic organisms, above all parasitic fungi and harmful insects. For instance, some literature sources state that the high (seeds) and coppice beech forests in Serbia host almost 150 species of fungi on their trees, some of which can be found on the cupules, fruit and seedlings, some on the leaves and branch and stem bark, and some cause wood decay and staining. It is important to emphasize that the beech forest decline has been caused by the interaction of the adverse effects of climate change and the management and biotic factors. One of these adverse factors is naturally the human activity. Unreasonable exploitation of beech forests in Serbia has almost halved the area under forest. The felling of beech forests in the past (especially immediately after the Second World War) was not aimed at forest regeneration, but almost exclusively at wood exploitation. Consequently, beech trees have become non-resistant to the harmful effects of numerous abiotic and biotic factors. Among them, the most serious biotic factors are parasitic fungi and harmful insects. The spread of the dangerous "beech bark disease" caused by the Cryptococcus fagisuga insect and the Nectria coccinea fungus makes the protection of beech forests even more difficult. This study shows that despite the fact that the beech is a very sensitive species, if proper care and management measures are carried out, beech trees can recover relatively quickly even from the substantial damage caused by natural disasters such as catastrophic ice storms. However, one must bear in mind the fact that the physiologically weakened trees are much more susceptible to the attack of dangerous diseases and pests, which in this case refers to the extremely dangerous "beech bark disease" that occurred in the study stand two years after the ice storm. It is therefore necessary to conduct regular monitoring of these localities in the coming period in order to prepare and implement programs of measures of adequate protection for the prevention of the damage of epiphytic proportions, which could easily spread to the surrounding non-infected areas.
\end{abstract}




\title{
СТАЫЕ КРУНА БУКОВИХ СТАБАЛА ПОСЛЕ КАТАСТРОФАЛНОГ ЛЕДОЛОМА НА ЦРНОМ ВРХУ
}

\author{
Мирослава МАРКОВИЋ, Снежана РАЈКОВИЋ, Ненад МАРКОВИћ
}

\section{Резиме}

Буква у шумској привреди има велики економски значај, пре свега као најраспрострањенија врста дрвећа у Србији, захваљујући неким одличним техничким особинама. Међутим, шира употреба буковог дрвета је ограничена њеном краткотрајношћу. Буково дрво је неотпорно и представља одличну подлогу за развој многих паразитних и сапрофитних организама, а међу њима на прво место долазе паразитне гљиве и штетни инсекти. У литератури се рецимо наводи да је у високим (семеним) и изданачким шумама букве у Србији, на стаблима букве констатовано готово 150 врста гљива, од којих се неке јављају на купулама, плодовима и понику, неке на лишћу и кори грана и стабла, а неке су проузроковачи трулежи и обојености дрвета. Важно је нагласити да је узрок појаве сушења у шумама букве последица истовременог негативног утицаја деловања климатских (промена климе), газдинских и биотичких чинилаца. Међу овим факторима посебно место заузима и човек, који је нерационалним искоришћавањем букових шума у Србији, у прошлости, површину под шумама скоро преполовио. Сече букових шума у прошлости (поготово непосредно после II светског рата) нису имале карактер сеча обнављања шума, већ скоро искључиво експлоатациони карактер. Као последица таквог односа према шуми, она је постала јако осетљива на штетно деловање бројних абиотичких и биотичких фактора. Међу биотичким чиниоцима посебно место заузимају паразитне гљиве и штетни инсекти. Појава опасне тзв. "болести коре букве", коју изазива инсект Cryptococcus fagisuga и гљива Nectria coccinea, што још више отежава проблем заштите букових шума. У раду је показано да иако је природно буква врло осетљива врста, уколико се врше правилне мере неге и газдовања, чак и после великих штета од природних непогода као што су ледоломи катастрофалних размера, стабла се релативно брзо опорављају. Без обзира на то, не сме се заборавити чињеница да су физиолошки ослабљена стабла у много већој мери подложна нападу опасних болести и штеточина, што се у овом случају односи на изузетно опасну наведену „болест коре букве“, која се јавила у испитиваној састојини две године након штете од ледолома. Зато је неопходно редовно праћење стања на оваквим локалитетима и у наступајућем периоду, ради припреме и спровођења програма мера адекватне заштите, да не би дошло до штета епифитотичних размера, које би се лако могле проширити и на околна, незаражена подручја. 